\title{
Response of Wheat (Triticum aestivum L.) to FYM and Phosphorus Application in Alluvial Soil
}

\author{
Binder Singh* and A.P. Singh \\ Department of Agricultural Chemistry and Soil Science, R.B.S. College, Bichpuri, \\ Agra - 283105 (U.P.), India \\ *Corresponding author
}

\section{A B S T R A C T}

\begin{tabular}{|l|}
\hline K e y w o r d s \\
NPK Nitrogen (N), \\
$\begin{array}{l}\text { Phosphorus (P) and } \\
\text { Potash (K), FYM } \\
\text { Farmyard Manure, RBD } \\
\text { Randomized Block } \\
\text { Design }\end{array}$ \\
\hline Article Info \\
\hline $\begin{array}{l}\text { Accepted: } \\
\text { 02 May 2018 } \\
\text { Available Online: } \\
\text { 10 June 2018 }\end{array}$ \\
\hline
\end{tabular}

\section{Introduction}

Wheat (Triticum aestivum L.) is one of the major cereal crops produced in the world (Anon 1971). India is the second largest producer of wheat in the world after China. Wheat is the second most important crop after rice in India. Production and productivity of wheat increased at a great level with the advent of the green revolution. Even the productivity increased at a good pace and was computed to be around $2989 \mathrm{~kg} /$ hectare in the report by the Indian Department of Agriculture (Agricultural Statistics at a glance
A field experiment was conducted at the research farm of R. B. S. College Bichpuri, Agra during the Rabi season of 2012-13 to determine the effects of Farmyard Manure (FYM) and phosphorus application on wheat crop in alluvial soil. The experiment was laid out in the randomized block design (RBD) with four levels of FYM (control, 2.5, 5.0 and $10 \mathrm{t}$ $\mathrm{ha}^{-1}$ ) and four levels of phosphorus (control, 40, 80 and $120 \mathrm{~kg} \mathrm{P}_{2} \mathrm{O}_{5} \mathrm{ha}^{-1}$ ) with three replications. Nitrogen, Phosphorus, and Potash (NPK) were applied in the form of urea, single super phosphate and muriate of potash respectively. Results revealed that the plant height, number of tillers $\left(\mathrm{m}^{-2}\right)$, number of spikes $\left(\mathrm{m}^{-2}\right)$, spike length $(\mathrm{cm})$, number of grain spike $^{-1}, 1000$ - grain weight and grain and straw yield of wheat crop improved by FYM and phosphorus application. The nutrient contents as $\mathrm{N}, \mathrm{P}, \mathrm{K}$ and $\mathrm{Zn}$ in grain and straw of wheat enhanced significantly with the application of FYM @ 10t ha ${ }^{-1}$ and phosphorus @ 80 $\mathrm{kg} \mathrm{P}_{2} \mathrm{O}_{5} \mathrm{ha}^{-1}$.This treatment also recorded highest grain yield of $33.5 \mathrm{q} \mathrm{ha}^{-1}$ as compared to rest of other treatments. Hence the application of FYM @ $10 \mathrm{t} \mathrm{ha}^{-1}$ and phosphorus @ 80 $\mathrm{Kg} \mathrm{P}_{2} \mathrm{O}_{5} \mathrm{ha}^{-1}$ is recommended to the farmer for getting better production of the wheat crop. 
the absence of gluten. The demand for good quality wheat for the malting and brewing is increasing fast.

Wheat has got special value keeping in view its industrial importance and its existence under problematic to grow successfully. Intensive cultivation has resulted in depletion of soil nutrients to a great extent, thus the nutrient requirement of the crops has increased considerably during the last years. Phosphorus is the backbone of the crop production and plays a key role in energy-related activities and development of root-system. The availability of phosphorus from soil to plants depends upon the equilibrium adjustment around the root zone. Most of the Indian soils have an inadequate supply of available phosphorus and hence need to supplement of $\mathrm{P}$ in the form of fertilizers for crop production.

The application of FYM in the soil helps in increasing the fertility of the soil as physical condition including its water holding capacity. Organic manures, which were perhaps the major sources of plant nutrients in traditional agriculture, receive less emphasis with the advent of high analysis chemical fertilizers.

The decision on the optimum use of fertilizer required knowledge of crop response to applied fertilizer, inherent nutrients by soil and its short or long-term fate effects (Dobermann et al., 2003). Without detracting from the fact that chemical fertilizer will continue to be the main instrument for quickening the pace for agricultural production the recent researches indicate that a judicious combination of organic manures and fertilizer better maintain the long-term soil fertility and sustain high levels of productivity. Therefore, use of both organic manure and chemical fertilizers in appropriate proportion assume special significance as complementary and supplementary to each other in crop production.
Keeping in view the above perspectives, the present research work was taken up to find out the "Response of wheat (Triticum aestivum L.) to FYM and phosphorus application in Alluvial soil',.

\section{Materials and Methods}

A field experiment was conducted at the research farm of R. B.S. College, Bichpuri, Agra during Rabi season of 2012-13. The soil of the experimental field was sandy loam in texture with $\mathrm{p}^{\mathrm{H}} 8.1$ (1:2.5 soil : water, Jackson, 1973), organic carbon $0.34 \%$ (Walkley and Black, 1934), available $\mathrm{N} 167.50 \mathrm{Kg} \mathrm{ha}^{-1}$ alkaline permanganate oxidizable N (Subbiah and Asija, 1956), available P $10.0 \mathrm{Kg} \mathrm{ha}^{-1} 0.5$ $\mathrm{N} \mathrm{NaHCO}$ extractable $\mathrm{P}$ (Olsen et al., 1954), exchangeable $\mathrm{K} 130.0 \mathrm{Kg} \mathrm{ha}{ }^{-1}$ neutral $N$ ammonium acetate exchangeable K (Hanway and Heidel, 1934) and DTPA extractable Zn $0.50 \mathrm{ppm}$. The experiment was laid out with three replication in Randomized Block Design with four FYM levels as control $\left(\mathrm{F}_{0}\right), 2.5\left(\mathrm{~F}_{1}\right)$, $5.0\left(\mathrm{~F}_{2}\right)$ and $10\left(\mathrm{~F}_{3}\right) \mathrm{t} \mathrm{ha}^{-1}$, four levels of phosphorus as control $\left(\mathrm{P}_{0}\right), 40\left(\mathrm{P}_{1}\right), 80\left(\mathrm{P}_{2}\right)$ and $120 \quad\left(\mathrm{P}_{3}\right) \quad \mathrm{Kg} \quad \mathrm{P}_{2} \mathrm{O}_{5} \mathrm{ha}^{-1}$. FYM was incorporated a week before sowing. The recommended dose of nitrogen and potassium were supplied to every plot through urea and muriate of potash, respectively. Phosphorus and potassium were applied as basal and urea was applied in three equal splits as basal, at CRI stage and at third irrigation. The variety of wheat PBW-550 was grown up to maturity. The crop was irrigated by tube well water as when required at different growth stages. Data of plant height, number of tillers $\left(\mathrm{m}^{-2}\right)$, number of spikes $\left(\mathrm{m}^{-2}\right)$, spike length $(\mathrm{cm})$, number of grain spike ${ }^{-1}, 1000$ - grain weight and grain and straw yield were taken on physical maturity at the time of harvesting. The data of field observations were recorded from ten plants in each plot selected randomly and grain and straw yield were determined by net area basis after border rows removed. 
Grain and straw samples were washed with distilled water to clean impurities, separately air-dried and oven dried to remove the moisture until constant weight was attained. After grinding in a Wiley mill, the samples were stored in wide mouth glass stopped bottle with proper labeling and subjected to the chemical analysis. The $\mathrm{P}$ in the digest was determined by the spectrophotometer, $\mathrm{K}$ by the flame photometer and total nitrogen was analyzed by Kjeldahl method (Bremner and Mulvaney, 1982).

\section{Results and Discussion}

\section{Plant growth}

It is evident from Table 1 that the plant height and number of tillers $\left(\mathrm{m}^{-2}\right)$ enhanced significantly with increasing levels of FYM as compared to control.

The maximum plant height and number of tillers were recorded with the dose of FYM (10 $\left.\mathrm{t} \mathrm{ha}^{-1}\right)$ application.

It is clear that FYM proved more beneficial in case of plant growth of wheat crop, it may be due to gradual mineralization and availability of nutrients along with moisture holding capacity of soil by FYM.

Similar results were also reported by Yadav et al., (2007), Bonde et al., (2009) and Kumar et al., (2010).

Further evaluations of data reflect that the plant height and number of tillers $\left(\mathrm{m}^{-2}\right)$ improved significantly with increasing doses of phosphorus as compared to control. However, the plant height and the number of tillers $\left(\mathrm{m}^{-2}\right)$ increased up to $\mathrm{P}_{3}(120 \mathrm{Kg}$ $\mathrm{P}_{2} \mathrm{O}_{5} \mathrm{ha}^{-1}$ ) level of phosphorus but in plant growth, it was not significantly better over $\mathrm{P}_{2}$ (80 Kg $\mathrm{P}_{2} \mathrm{O}_{5} \mathrm{ha}^{-1}$ ) level of phosphorus. This increase might be due to the well-developed root system, which might have helped in the availability of nutrients to the plants. Similar to these findings are of Kumawat et al., (2004) and Singh et al., (2010).

\section{Yield and yield attributes}

The data (Table 1) indicates that yield attributes like the number of spikes $\left(\mathrm{m}^{-2}\right)$, spike length $(\mathrm{cm})$, the number of grain spike ${ }^{-1}$ and test weight increased significantly with each increasing dose of FYM over control. The maximum grain and straw yield of wheat was recorded with the highest level of FYM (10 $\left.\mathrm{t} \mathrm{ha}^{-1}\right)$. Kumar et al., (2010) and Jaga et $a l$. , (2011) reported similar to these findings.

There was a significant increase in the yield and yield attributes characters with the application of phosphorus. The grain and straw yield of wheat enhanced significantly up to $80 \mathrm{Kg} \mathrm{P}_{2} \mathrm{O}_{5} \mathrm{ha}^{-1}$. The phosphorus levels as control, 40, 80 and $120 \mathrm{Kg} \mathrm{ha}^{-1}$ result 14.50, 27.86 and 22.90 percent enhancement in grain yield over control, respectively. Similarly the 14.84, 19.60 and 21.00 percent enhancement in straw yield over control, respectively.

This favorable effect might be owing to the fact that phosphorus is well known for its role in development and energy transformation in various vitally important metabolic processes in the plant, the beneficial results of phosphorus application was also earlier reported by Pathan et al., (2010) and Dixit et al., (2011).

\section{Nutrient composition}

The Table 2 indicate that nutrient contents $(\mathrm{N}$, $\mathrm{P}, \mathrm{K}$, and $\mathrm{Zn}$ ) in grain and straw of wheat enhanced significantly with increasing levels of FYM as compared to control. The highest level of FYM (10 $\left.\mathrm{t} \mathrm{ha}^{-1}\right)$ gave better performance over rest of the treatment in case of the nutrient composition of the wheat crop. 
Table.1 Effect of FYM and phosphorus on plant height $(\mathrm{cm})$, number of tillers $\left(\mathrm{m}^{-2}\right)$, number of number of spikes $\left(\mathrm{m}^{-2}\right)$, spike length $(\mathrm{cm})$, grain spike ${ }^{-1}$, test weight $(\mathrm{g})$, grain and straw yield $\left(\mathrm{q} \mathrm{ha} \mathrm{h}^{-1}\right)$ of the wheat crop

\begin{tabular}{|c|c|c|c|c|c|c|c|c|}
\hline Treatment & $\begin{array}{c}\text { Plant } \\
\text { height } \\
\text { (cm) }\end{array}$ & $\begin{array}{c}\text { Number } \\
\text { of tillers } \\
\left(\mathrm{m}^{-2}\right)\end{array}$ & $\begin{array}{c}\text { Number } \\
\text { of spikes } \\
\left(\mathrm{m}^{-2}\right)\end{array}$ & $\begin{array}{l}\text { Spike } \\
\text { length } \\
\text { (cm) }\end{array}$ & $\begin{array}{l}\text { Grain } \\
\text { spike }^{-1}\end{array}$ & $\begin{array}{c}\text { Test } \\
\text { weight } \\
\text { (g) }\end{array}$ & $\begin{array}{l}\text { Grain } \\
\text { yield (q } \\
\text { ha }^{-1} \text { ) }\end{array}$ & $\begin{array}{l}\text { Straw } \\
\text { yield (q } \\
\text { ha }^{-1} \text { ) }\end{array}$ \\
\hline \multicolumn{9}{|l|}{ FYM level } \\
\hline $\mathbf{F}_{0}$ & 80.15 & 330 & 305.5 & 8.70 & 22.5 & 37.85 & 26.5 & 35.7 \\
\hline$F_{1}$ & 85.20 & 351 & 336.4 & 9.09 & 23.4 & 38.79 & 30.5 & 41.0 \\
\hline$F_{2}$ & 89.10 & 369 & 342.1 & 9.40 & 24.0 & 39.15 & 31.8 & 42.7 \\
\hline$F_{3}$ & 93.28 & 388 & 355.2 & 10.28 & 24.2 & 39.50 & 32.7 & 43.2 \\
\hline S. Em \pm & 1.19 & 3.83 & 3.02 & 0.226 & 0.981 & 0.461 & 0.021 & 0.042 \\
\hline $\begin{array}{l}\text { C.D. at } \\
5 \%\end{array}$ & 3.37 & 10.82 & 8.55 & 0.64 & 2.77 & 1.30 & 0.06 & 0.12 \\
\hline \multicolumn{9}{|l|}{$\begin{array}{l}\text { Phosphoru } \\
\text { s level }\end{array}$} \\
\hline $\mathbf{P}_{0}$ & 80.10 & 332 & 307.1 & 8.68 & 22.6 & 37.75 & 26.2 & 35.5 \\
\hline $\mathbf{P}_{1}$ & 85.10 & 353 & 334.2 & 9.50 & 23.5 & 38.60 & 30.0 & 40.6 \\
\hline $\mathbf{P}_{2}$ & 90.55 & 388 & 357.1 & 10.12 & 24.3 & 39.55 & 33.5 & 45.0 \\
\hline $\mathbf{P}_{3}$ & 92.85 & 397 & 358.1 & 10.15 & 24.0 & 39.55 & 32.2 & 43.4 \\
\hline S. Em \pm & 1.19 & 3.83 & 3.02 & 0.226 & 0.981 & 0.461 & 0.021 & 0.042 \\
\hline $\begin{array}{l}\text { C.D. at } \\
5 \%\end{array}$ & 3.37 & 10.82 & 8.55 & 0.64 & 2.77 & 1.30 & 0.06 & 0.12 \\
\hline
\end{tabular}

Table.2 Effect of FYM and phosphorus on nutrient composition of the wheat crop

\begin{tabular}{|c|c|c|c|c|c|c|c|c|}
\hline Treatment & \multicolumn{2}{|c|}{ Nitrogen (\%) } & \multicolumn{2}{|c|}{ Phosphorus (\%) } & \multicolumn{2}{|c|}{ Potassium (\%) } & \multicolumn{2}{|c|}{ Zinc (ppm) } \\
\hline & Grain & Straw & Grain & Straw & Grain & Straw & Grain & Straw \\
\hline \multicolumn{9}{|l|}{ FYM levels } \\
\hline $\mathrm{F}_{0}$ & 2.40 & 0.403 & 0.55 & 0.042 & 0.42 & 1.52 & 12.6 & 11.0 \\
\hline$\overline{F_{1}}$ & 2.56 & 0.433 & 0.57 & 0.048 & 0.49 & 1.87 & 14.5 & 12.7 \\
\hline $\mathrm{F}_{2}$ & 2.70 & 0.460 & 0.60 & 0.052 & 0.54 & 2.18 & 17.0 & 14.0 \\
\hline $\mathrm{F}_{3}$ & 2.88 & 0.471 & 0.64 & 0.056 & 0.60 & 2.46 & 20.7 & 16.9 \\
\hline S. Em \pm & 0.050 & 0.0025 & 0.005 & 0.001 & 0.010 & 0.078 & 0.67 & 0.47 \\
\hline C.D. at 5\% & 0.14 & 0.007 & 0.015 & 0.003 & 0.03 & 0.22 & 1.88 & 1.35 \\
\hline \multicolumn{9}{|c|}{ Phosphorus levels } \\
\hline $\mathbf{P}_{0}$ & 2.40 & 0.402 & 0.54 & 0.044 & 0.43 & 1.50 & 13.0 & 11.3 \\
\hline $\mathbf{P}_{1}$ & 2.54 & 0.432 & 0.58 & 0.047 & 0.50 & 1.90 & 15.3 & 12.5 \\
\hline $\mathbf{P}_{2}$ & 2.84 & 0.466 & 0.66 & 0.057 & 0.61 & 2.52 & 20.8 & 15.5 \\
\hline $\mathbf{P}_{3}$ & 2.68 & 0.458 & 0.62 & 0.051 & 0.58 & 2.20 & 18.5 & 13.8 \\
\hline S. Em \pm & 0.050 & 0.0025 & 0.005 & 0.001 & 0.010 & 0.078 & 0.67 & 0.47 \\
\hline C.D. at $5 \%$ & 0.14 & 0.007 & 0.015 & 0.003 & 0.03 & 0.22 & 1.88 & 1.35 \\
\hline
\end{tabular}


In general, the nutrient composition of wheat improved by the application of FYM. It might be due to greater availability of nutrients under adequate supply of available nutrients by FYM application. Pathan et al., (2010) and Sisodia et al., (2010) reported similar to these findings.

Further, it could be inferred from Table 2 that the $\mathrm{N}, \mathrm{P}, \mathrm{K}$ and $\mathrm{Zn}$ contents in grain and straw of wheat crop increased with higher levels of phosphorus application. It was interesting to note that the nutrient contents in grain and straw of wheat improved up to $80 \mathrm{Kg} \mathrm{P}_{2} \mathrm{O}_{5}$ $\mathrm{ha}^{-1}$, which may be due to improvement in the nutritional environment of rhizosphere and uptake of nutrients by the wheat crop. Similar results were also reported by Patel et al., (2005), Islam et al., (2005) and Singh et al., (2010).

The higher dose of FYM (10 $\left.\mathrm{t} \mathrm{ha}^{-1}\right)$ application significantly increased the grain and straw yield over the control besides improved the content and uptake of nitrogen, phosphorus, potassium, and zinc by wheat crop. And the similar result was recorded with $80 \mathrm{Kg} \mathrm{P}_{2} \mathrm{O}_{5} \mathrm{ha}^{-1}\left(\mathrm{P}_{2}\right)$ level of phosphorus application. Hence the application of FYM @ $10 \mathrm{t} \mathrm{ha}^{-1}$ and phosphorus @ $80 \mathrm{Kg} \mathrm{P}_{2} \mathrm{O}_{5} \mathrm{ha}^{-1}$ is recommended to the farmer for getting better production of the wheat crop.

\section{References}

Anonymous. 1971. Production year Book, FAO, Rome. 25: 37-41.

Bhandari, A.L., Ladha, J.K., Pathak, H., Padre, A.T., Dawe, D. and Gupta, R.K. (2002) Yield and soil nutrientchanges in a long-term rice-wheat rotation in India. Soil Science Society of America Journal 66, 162-170.

Bonde, A.S., Deshmukh, P.A., Band, S.B., Bhurghate, S.K. and Deshmukh, S.B. (2009). Effect of organic and inorganic sources of phosphorus on yield attributes and yield of wheat. Ann. Pl. Soil Res. 11 (2): 98-99.

Dixit Ashish, Dawson Joy, Verma Rajan, Diwan Paravati and Kishore Prem (2011). Effect of integrated used of chemical on organic sources of nitrogen on growth and yield of barley.Ann. $\mathrm{Pl}$. Soil Res. 13 (1): 67-68.

Dobermann, A., Witt, C., Abdulrachman, S., Gines, H. C., Nagarajan, R., Son, T.T., Tan, P. S., Wang, G. H., Chien, N. V. and Thoa, V. T. K. 2003. Soil fertility and indigenous nutrient supply in irrigated rice domains of Asia. Agron. J. 95: 913-923.

Islam, M.N., Hoque, S. and Islam, A. (2005). Interaction effects of phosphorus and zinc in wheat, rice, and mungbean. $J$. Indian Soc. Soil Sci., 53 (2): 221-227.

Jaga, P.K., and Tripathi, P.N. (2011). Effect of integrated plant nutrient supply on productivity and economics of pearl millet-mustard crop sequence. Ann. of plant and soil research 13(1): 20-24.

Kumar, P., Singh, A. and Singh, A.K. (2010). Effect of bio-fertilizers, farmyard manure and nitrogen levels on growth yield and uptake of nutrients in wheat.Ann. Pl. Soil Res. 12 (2): 92-94.

Kumavat, B. L., Pathan, A. R. K. and Chauhan, R. (2004). Response of taramira to sulphur and phosphorus application on type psamment. J. Indian Soc. Soil Sci., 52 (4): 476-478.

Patel, A. Namedo, K.N. and Saraiya, A.B. (2005). Effect of phosphorus and growth regulators on growth, yield and nutrient uptake of Black gram. Ann. Pl. Soil Res. 7 (1): 41-43.

Pathan, A. R. K. (2010). Effect of FYM in phosphorus on the performance of Fenugreek Irrigated with saline water Ann. pl. Soil Res. 12 (2): 153-155.

Pathan, A.R.K. Nag, A.K., Singh, V. and Singh, C. (2010). Response of 
fenugreek to FYM, phosphorus and saline water irrigation. Ann. Pl. Soil Res. 12 (1): 27-29.

Singh, M.V., Kumar, N., Singh, R.K. and Misra, B.N. (2010). Effect of phosphorus, sulphur, and zinc on growth, yield and uptake of nutrients in late sown wheat in Eastern Uttar Pradesh. Ann. Pl. Soil Res. 12 (2): 119121.
Sisodia, R.S., Pandey Manoj, and Pal Anil (2010). Response of oat to FYM under sodic water irrigation Ann. Pl. Soil Res. 12 (2): 86-88.

Yadav, B.R., Chippa, B.R. and Pathan, A.R.K. (2007). Effect of FYM and iron on yield attributes and yield of barley under graded levels of alkalinity. Ann. Pl. Soil Res. 9 (2): 176-177.

\section{How to cite this article:}

Binder Singh and Singh, A.P. 2018. Response of Wheat (Triticum aestivum L.) to FYM and Phosphorus Application in Alluvial Soil. Int.J.Curr.Microbiol.App.Sci. 7(06): 418-423. doi: https://doi.org/10.20546/ijcmas.2018.706.047 